\title{
Making English grammar meaningful to non-grammarians: the grammatical categories.
}

\author{
${ }^{1}$ Ebibi, Johnson Ojeka, ${ }^{2}$ Nnaji, Patience Onyinyechi, ${ }^{3}$ Ebibi, Rosemary Abeyi \\ ${ }^{I}$ Department of Remedial Sciences University of Jos NIGERIA. \\ ${ }^{2}$ Dept of Television Journalism NTA Television College (an affiliate of Ahmadu Bello University, Zaria, \\ NIGERIA \\ ${ }^{3}$ Erdoo Memorial Nursery and Primary school Makurdi Benue State NIGERIA.
}

\begin{abstract}
English grammar is an interesting field of study because of its variety. It is a universal field as its applicability cuts across all human endeavours especially in countries like Nigeria where English is used as the official language. Grammar is to the English language as the heart is to a human being. The user's mastery of it determines his competence and performance in every sphere of life. Thus a grammar-deficient person will only be postponing the evil days to say he/she is not a grammarian and so the study of grammar does not appeal to him. This paper used the descriptive research design to discuss the meaning, importance of English grammar in general and made grammatical structures meaningful not only to grammarians but also to people in other professions. This would help the latter to remedy any deficiencies in the use of these aspects of grammar and enhance or facilitate their daily interactions and effective communication in their chosen professions and the society at large.
\end{abstract}

\section{Introduction}

English grammar as earlier pointed out, is not only an interesting field of study but also an indispensible body of knowledge. It is disheartening to hear near-accomplished professionals, chief executives of reputable organizations, respected preachers and highly placed government officials etc speak English with avoidable abuse of grammatical rules. This is traceable to their lack of knowledge of this all important but sometimes the most neglected part to an individual's success. A good knowledge of grammar has become imperative because the more we know of grammar the better we are as human being. It is no wonder Crystal (2006) observes that: grammar is the structural foundation of our ability to express ourselves; the more we are aware of how of it works, the more we can monitor the meaning and effectiveness of the way we and others use language. It can foster precision, detect ambiguity and exploit the richness of expression available in English. And it can help everyone - not only teachers of English, but a teacher of anything, for all teaching is ultimately a matter of getting to grips with meaning (No page indicated).

Grammar is an important ingredient of every human language. It has been defined in various ways by different people. While some define it according to the constituent or structure of a sentence, others define it by the meaning a sentence conveys; yet others define grammar by the function a sentence performs and some the correctness or otherwise of an utterance.

American Heritage Dictionary of English (2009) defines grammar as a branch of linguistics that deals with syntax and morphology sometimes also phonology and semantics of a language. It further defines grammar as the use of language with regards to its correctness or social propriety, especially in syntax. Grammar is defined as a set of rules and examples dealing with the syntax and word structure (morphology) of a language (Nordquist, 2014). It is concerned with how sentences and utterances are formed. Eka (2004) defines it as a branch of language study which deals with the construction of sentences which are intelligible and acceptable to the native and non native speakers educated in a given language. Tomori (1977) explains grammar in a restricted sense when he defined it as the quality of the knowledge of a language possessed by a speaker as inferred from the nature of his utterances.

In grammar, a word can mean different things depending on the context in which it is used- verb, adverb, noun, pronoun, adjective preposition, conjunction and interjection called parts of speech or word class. Similarly, a sentence can imply a variety of time: past, present and future as a result of the change that occurs in the form of the verb. A sentence can also imply: a command, a request, a question, a request and a declaration when the mood of the speaker is taken into account. The action of a verb may be in progress (continuous) or completed (perfect) and sometimes as habitual (repetitive). Consequent upon this English has different grammatical categories such as: aspect, tense, case, mood and gender among others which are the focus of this paper. 


\section{Grammatical Aspect}

Aspect concerns the manner in which the verbal action is expressed or regarded. For example, as completed or in progress (Quirk \& Greenbaum, 2000). According to Wikipedia, the free encyclopedia (2014) aspect is a grammatical category that expresses how an action, event or state denoted by a verb relates to the flow of time. It further states that a basic aspectual distinction is that between perfective (completed actions) and imperfective aspects (in progress or repetitive). In other words, aspect is concerned with whether the action of a verb is considered to have been completed or it is still in progress or repetitive. One should not be confused with perfect and imperfect verb forms because the meanings of the latter terms are somewhat different. Perfect aspect is used in referring to an event concerned as bounded and unitary without any flow of time during it e.g. $\mathrm{I} / \mathrm{We} / \mathrm{They} / \mathrm{She} / \mathrm{He} / \mathrm{It}$ helped him. Progressive aspect is used for situations conceived as existing continuously or repetitively as time flows e.g.

I was helping him.

We/They were helping them/us.

I used to help people.

We/They used to help people.

Further distinctions can be made for example to distinguish states and ongoing action (continuous and progressive aspects) from repetitive or habitual actions. These have been adequately treated under 'tense' in the latter part of this paper.

Aspect is often confused with the closely related concept of tense because both convey information about time. While tense relates the time of referent to some other time, aspect conveys other temporal information, such as duration, completion or frequency as it relates to the time of action. Thus tense refers to temporarily when e.g.

$\mathrm{I} / \mathrm{We}$ eat; She/He/It eats.

while aspect refers to temporarily how e.g.

$\mathrm{I} /$ We have eaten; She/he/it has eating OR He/She/It is eating.

Aspect can be said to describe the texture of the time in which a situation occurs, such as a single point of time, a continuous range of time, a sequence of discrete points in time etc whereas tense indicates its location (Quirk \& Greenbaum, 2000). Example:

I eat.

I am eating.

I have been eating.

All the sentences above are in the present tense as they describe the present situation yet each conveys different information or points of view as to how the action pertains to the present. As such, they differ in aspect.

\section{Grammatical Tense}

Tense, aspect, time and verb are seeming inseparable but distinctive elements in grammar. The verb and tense collaborate to indicate the time of an action or to indicate when an action occurs, occurred or would occur and how it occurs. Tense means a change in the form of a verb to indicate time. In other word, when a verb; for example see changes to saw in a sentence, the idea of time has been introduced. The sentences below illustrate it better:

John visits us regularly- present.

John visited us this morning- past. The idea of time past has been introduced in the second sentence with the change of the verb form from visits to visited.

Daddy gives us pocket money monthly- present

Daddy gave us pocket money lasr month-past

The man is cleaning the office- present

The man was cleaning the office- past

Eka (2004) defines tense as any systematic device for expressing time relation and location. Tense is the correspondence between the form of the verb and our concept of time (Quirk \& Greenbaum, 2000). They further posit that the English tense-aspect system has two morphologically distinct tenses, present and past. No marker of a future tense exists on the verb in English; the futurity of an event may be expressed through the use of modal auxiliaries will and shall, by a present form plus an adverb as in Tomorrow, we go to Lagos or by some other means. Past is distinguished from present-future in contrast with internal modifications of the verbs. These two tenses may be modified further for progressive aspect (continuous aspect) for the perfect or for both. These two aspectual forms are also referred to as be+ing and have+en respectively (Quirk \& Greenbaum, 2000). 
Aspects of the Present Tense:

Present simple (not progressive; not perfect). Example:

I / We or The children eat.

$\mathrm{He} / \mathrm{She}$ or It or The child eats.

Present progressive (progressive, not perfect). Example:

I am eating; We/they are eating.

$\mathrm{He} / \mathrm{She}$ or It is eating.

Present perfect (not progressive, perfect). Example:

$\mathrm{I} / \mathrm{We} / \mathrm{The}$ students have eaten.

$\mathrm{She} / \mathrm{He} / \mathrm{It} /$ or The student has eaten.

Present perfect progressive (progressive, perfect). Example:

$\mathrm{I} / \mathrm{We}$ or The women have been eating.

$\mathrm{She} / \mathrm{He} / \mathrm{It}$ or The woman has eaten.

Many elementary English grammar books classify the present prefect tense as a past tense. This is incorrect because it relates the action to the present time. For instance, it is wrong to say of someone now dead that he has eaten or has been eating. The present auxiliary implies that he is in some way present alive even if the action denoted is completed (perfect) or partially completed (progressive perfect).

\section{Aspects of Past Tense}

Wikipedia, the free Encyclopedia (2014) gives the aspects the tenses as follows:

Past simple (not progressive, not perfect). Example:

$\mathrm{I} / \mathrm{We}$ ate.

$\mathrm{He} / \mathrm{She}$ or It ate.

Past progressive (progressive, not perfect). Example:

I/ She/He/It or The girl was eating.

We/They or The girls were eating.

Past perfect (not progressive, perfect). Example:

I/We had eaten.

$\mathrm{He} / \mathrm{She}$ or It had eaten.

Past perfect progressive (progressive, perfect). Example:

$\mathrm{I} /$ We had been eating

. He/She or It had been eating.

\section{Aspects of Future Tense:}

It should be noted that the aspect of future does not react to any change in the subject. In other words, whether the subject is singular or plural the verb form does not change as is the case with the present and progressive past thus we have:

Simple future, simple conditional. Example:

I/We will eat.

I/We would eat.

$\mathrm{He} / \mathrm{She} / \mathrm{It}$ will eat; $\mathrm{He} / \mathrm{She}$ or It would eat.

Future progressive; conditional progressive. Example:

$\mathrm{I} / \mathrm{We}$ will be eating; I/We would be eating.

$\mathrm{She} / \mathrm{He}$ or It will be eating. She/He or It would be eating

Future perfect; conditional perfect. Example:

I/We will have eaten; I/We would have eaten.

$\mathrm{She} / \mathrm{He}$ or It will have eaten. She/He or It would have eaten.

Future perfect progressive; future perfect conditional. Example:

$\mathrm{I} / \mathrm{We}$ will have been eating; I/We would have been eating.

$\mathrm{He} / \mathrm{She}$ or It will have been eating. He/She or It would have been eating.

Note that the use of some progressive and perfect aspects are quite complex as they may refer to the view point of the speaker.

\section{Grammatical Case}

Case is a grammatical category whose value reflects the grammatical functions performed by a noun, pronoun in a phrase, clause or sentence (Wikipedia, 2014). In some languages, nouns, pronouns and other modifies take different inflected forms depending on what case they are in. English has largely lost its case system although case distribution can still be seen with the person; forms such as I, he and we are used in the role of subject (Richardson, 2007). For example, 
I kicked the ball.

He kicked the ball.

We kicked the ball.

While forms such as me, him and us are used in the role of object.

John kicked me

They kicked us

David told him.

The commonest cases used in English are nominative, accusative, dative and genitive.

The nominative case indicates the subject of a finite verb. Example:

$\mathrm{We} / \mathrm{She} / \mathrm{He} / \mathrm{It}$ went to the store.

The accusative case indicates the direct object. Example:

The clerk remembered him/us/them.

The dative case indicates the indirect object a verb. Example

The clerk gave a discount to us.

David gave a gift to him/her.

The genitive which roughly corresponds to English's possessive case and preposition of indicates the possessor of a person or an object.

John's book was on the table. OR

His book was on the table.

The pages of the book turned yellow. OR

The book's pages turned yellow.

The following are other case forms that no longer exist or less emphasized in the present day English.

The ablative case indicates movement from something or causes

The victim went from into see the doctor and was unhappy because of depression.

The vocative case indicates an address

John, are you alright or simply Hello, John.

The locative case indicates a location.

We live in Makurdi.

The instrumental case indicates an object used in performing an action

We wipe the floor with a mop.

The mail was delivered by hand.

Opara \& Yilben (2011) summarize personal pronouns in a tabular form thus:

\begin{tabular}{|l|l|l|l|l|}
\hline Person and number & Subject case & Object case & Possessive case & Reflexive case \\
\hline $1^{\text {st }}$ person singular & I, we & Me, us & Mine, ours & Myself, ourselves \\
\hline $2^{\text {nd }}$ person singular & You & You & Yours & Yourself \\
\hline $3^{\text {rd }}$ person singular & He, she, it & Him, her, it & His, hers, its & $\begin{array}{l}\text { Himself, herself, } \\
\text { itself }\end{array}$ \\
\hline Plural & They & Them & Thiers & Themselves. \\
\hline
\end{tabular}

\section{Grammatical Mood}

Wikipedia, (2014) asserts that grammatical mood is a grammatical (and specifically, morphological) feature of verbs used to signal modality. That is, it is the use of verb inflections that allows speakers to express their attitude towards what they are saying (for example, whether it is intended as a statement of fact, of desire, of command or of request etc. Quirk \& Greenbaum (2000) say mood relates the verbal action to such conditions as certainty, obligation, necessity and possibility. Some examples of mood are: indicative, interrogative, imperative, emphatic, subjunctive, injunctive, optative and potential. For the scope of this paper, only the first four examples of mood will be considered besides, some of them are redundant or do not exist in English while a few others have lost their relevance in the present day English usage.

Indicative mood

The indicative or evidential mood is used for factual statements and positive beliefs. Example

The man is eating rice- a statement

God is almighty- positive belief

Imperative mood

Imperative mood expresses direct command, prohibitions and requests. Example

David, go and do your assignment now- a command

Answering calls in the banking hall is prohibited- a prohibition

Could you kindly lend me your biro please? - Request.

Interrogative mood

Interrogatory mood is used to ask questions. Example 
Where are you going after this lecture?

Who is your neighbour?

Emphatic mood

Emphatic mood is used to emphasize a point, subject, verb, object or other elements of a sentence. Example

Kate should do that work not her sister.

I gave him a car not a motorcycle.

\section{Grammatical Gender}

Genders are classes of nouns reflected in the behavior of associated words. Common gender divisions include masculine, feminine and neuter. Grammatical gender manifests itself when words related to a noun like determiners, pronouns or adjectives change their form (inflection) according to the gender of the noun they refer to (agreement). (Wikipedia,2014).

English makes very few gender distinctions. Where they are made, the connection between the biological category sex and the grammatical category gender is very close, in so far as natural sex distinctions determine gender distinctions. It is further typical of English that special suffixes are not generally used to mark gender distinctions nor are gender distinctions made in the article. Some pronouns are gender-sensitive (Quirk \& Greenbaum, 2000). For instance, the personal pronoun he is generally used in place of male gender while she is used for females. In some expressions, the objective case her which is originally for used for female gender is often used in place of countries, institutions and other such special usages. Example:

Nigeria got her independence in 1960 instead of its which is what is grammatically acceptable.

\section{Personal: masculine/feminine nouns.}

These nouns are two types. Type I has no overt marking that suggests morphological correspondents between masculine and feminine, whereas type II the two gender forms have a derivational relationship

\begin{tabular}{|l|l|l|l|}
\hline Masculine & Feminine & Masculine & Feminine \\
\hline Bachelor & Spinster & king & queen \\
\hline brother & Sister & man & woman \\
\hline father & Mother & monk & nun \\
\hline gentleman & gentle lady & uncle & aunt \\
\hline Nephew & Niece & \multicolumn{2}{|}{} \\
\end{tabular}

\begin{tabular}{|l|l|l|l|}
\hline Bridegroom & Bride & prince & princess \\
\hline Emperor & Empress & steward & stewardess \\
\hline Duke & Duchess & waiter & waitress \\
\hline God & Goddess & widower & widow \\
\hline Hero & Heroine & usher & Usheress (BrE) \\
\hline
\end{tabular}

(Quirk \& Greenbaum, 2000)

\section{Personal dual gender}

\begin{tabular}{|l|l|l|l|}
\hline Artist & Fool & parent & servant \\
\hline Chairman & Criminal & Liberian & person \\
\hline Cook & Friend & novelist & neighbour \\
\hline Doctor & Guest & teacher & musician \\
\hline Enemy & Inhabitant & writer & foreigner \\
\hline Professor & student & speaker & engineer \\
\hline
\end{tabular}

(Quirk \& Greenbaum, 2000)

\section{Collective Nouns}

Class, army, club, committee, crew, crowd, folk, gang, government, group, herd, jury, majority. Aristocracy, the bourgeoisie, the clergy, the elite, the gentry, the intelligentsia, the laity etc.

Animals

\begin{tabular}{|c|c|c|c|}
\hline buck & doe & gander & goose \\
\hline bull & cow & lion & lioness \\
\hline cock & hen & stallion & mare \\
\hline dog & bitch & tiger & tigress \\
\hline
\end{tabular}


$\underline{\text { Pronouns }}$

Neuter

Pronouns such as they, it, us, their, theirs and them with some reflexives are all neutral pronouns as they are neither masculine nor feminine bias can be used for animate and inanimate beings. In order words, their applicability is neither peculiar to any of the genders. For instance, It could be used to replace a new born baby whose sex is unknown to the speaker or listener e.g.

She had a baby and it began to cry. It refers to the baby.

The book fell down and it was picked by David. It refers to the book.

The books fell down and David picked them. Them refers to books

John and Obinna visited us this morning to inform us that they will be travelling to Lagos. They really enjoyed their stay with us.

Note that all the pronouns used in the sentence above and highlighted for recognition do not indicate the sex as either male or female as some others would do. The usage is neutral thus they are called neuter pronouns. The above illustration has by no means exhausted the list of neuter pronouns.

\section{Conclusion}

An In-depth knowledge of use of grammatical aspect, tense, case, mood, gender and other categories not discussed in this paper for want of space is required of all speakers of English if they want to be held as intelligible speakers and or teachers of the language. Conscious effort should therefore be made by both the teachers and learners of English to learn the principles governing their usage and also apply them appropriately at all times.

\section{References}

[1]. American Heritage Dictionary of the English Language (2000). Fourth Edition, New Jersey:Houghton Mifflin Company.

[2]. Eka, D. (2004). Elements of grammar and mechanics of the English language. Uyo: Samuf (Nigeria) Ltd.

[3]. MacDonald, J .E. (2008). The syntactic nature of inner aspect: A minimalist perspective. Amsterdam: John Benjamin Pub Company.

[4]. Opara, B. O. \& Yilben, J. J. (2011). Use of English: A concise text. Pankshin. Eureka Academic Foundation.

[5]. Quirk, R. \& Greenbaum, S. (2000). A university grammar of English. Edinburg: Pearson Education Limited.

[6]. Tense, aspect, case, mood and gender (2014) In Wikipedia, the free Encyclopedia. Retrieved February 10, 2014, from http://www.wikipedia.org/wiki/grammatical-case. . 